Bollobás, Enikő. “Arany, Zsuzsanna. Kosztolányi Dezső élete ['The Life of Dezső Kosztolányi’]. Budapest: Osiris, 2017. 692 pp. Illus." Hungarian Cultural Studies. e-Journal of the American Hungarian Educators Association, Volume 11 (2018) DOI: 10.5195/ahea.2018.331

\title{
Arany, Zsuzsanna. Kosztolányi Dezsö élete ['The Life of Dezső Kosztolányi']. Budapest: Osiris, 2017. 692 pp. Illus.
}

\author{
Reviewed by Enikő Bollobás* , Eötvös Loránd University, Budapest
}

After almost three decades since the end of communism in Central and Eastern Europe, scholars of Hungarian literature and culture have not yet filled in the gaps created by more than forty years of communism's reign in the region by writing and publishing works they could not have conceived of or carried out under communism. Responding to this need, the profession of literature has, since the regime change of 1990, steadily spurred an unprecedented flow of publications. Literary historians have showed an unwavering commitment to bring out critical and annotated editions, uncut original versions of novels, poetry and drama collections, and works that never made it through party censorship and remained in desk drawers for three, four, five, or by now six and even seven decades. Literary critics are similarly dedicated to writing much wanted basic works: literary histories, period histories, histories of literary schools and journals, biographies, and critical monographs on major authors. The biography of Dezsö Kosztolányi (1885-1936) has until recently been one such unwritten basic work.

One of the grand masters of twentieth century Hungarian literature, poet, prose writer, translator, critic, essayist, journalist, and editor Kosztolányi was both loved and hated, praised and denounced, owned and disowned by his time's changing and inevitably politically tainted critical schools. As we learn from Zsuzsanna Arany's meticulous study, which is substantiated by primary sources including manuscript materials and archival records whenever available, all these attitudes were dynamically varied. Indeed, over the years some denounced him as a communist fellow-traveler for his role in the short-lived Hungarian Soviet Republic, while others attached to him the stigma of bourgeois for his dispute with Georg Lukács and for not being more socially committed in his later years; some condemned him for being a member of the Freemason Society and publishing in its journal, Világ ['The World'], while still others branded him an anti-Semite for his articles in the "Pardon" column of the extreme right-wing journal $U j$ Nemzedék ['New Generation']. He was called a nationalist for denouncing the post-World War I Trianon Treaty, whereby Hungary lost two thirds of its territories, including Kosztolányi's birth town of Szabadka in the Vajdaság county (or Subotica in today's Voivodina of Serbia), but also an internationalist for his command of many languages, his acting as the President of the Hungarian PEN Club, and for translating Czech, Slovak, Romanian, and Serbian authors, whose countries had, in World War I, turned against Hungary. Based on his writings, Kosztolányi was

*bollobas.eniko@btk.elte.hu

$($ (c) $)$ EY

ULIS D-Serk
New articles in this journal are licensed under a Creative Commons Attribution 4.0 International License.

This journal is published by the University Library System of the University of Pittsburgh as part of its D-Scribe Digital Publishing Program and is cosponsored by the University of Pittsburgh Press 
Bollobás, Enikő. “Arany, Zsuzsanna. Kosztolányi Dezső élete ['The Life of Dezső Kosztolányi’]. Budapest: Osiris, 2017. 692 pp. Illus." Hungarian Cultural Studies. e-Journal of the American Hungarian Educators Association, Volume 11 (2018) DOI: 10.5195/ahea.2018.331

designated an aesthete for his l'art pour l'art ideas of literature, but also a social critic for his critical journalism of pre- and interwar society and everyday life. Finally, as to his personality, the charges ran from fairy for his gender sensitivity and homosocial alliances to womanizer for his taste for cheap women.

Critical opinion about Kosztolányi's work kept changing several times over the decades since his death. First a veritable cult developed around his memory, set off by the high praise of his contemporaries such as Mihály Babits, Sándor Márai, and Frigyes Karinthy. Then dailies like Népszava ['The People's Voice'] launched their attacks on the late writer's purportedly reactionary political views. At the root of the interwar political left's condemnation of Kosztolányi lay the memory of the Kosztolányi-Lukács conflict from the time of the 1919 Hungarian Soviet Republic. The philosopher-commissar's denunciation determined Kosztolányi's post-1945 rating as well; indeed, in the 1950s, the official Marxist verdict put injurious labels on Kosztolányi, making him out as bourgeois and gentry, reactionary and decadent, individualistic and existentialist, nationalist and irredentist, immoral and even protofascist. Ágnes Heller's 1957 monograph, Az erkölcsi normák felbomlása ['The Break-Up of Moral Norms'] (Budapest: Kossuth) stands out as a typical 1950s example of ideological criticism in its serving of the reigning party line. Arany claims in her book that Heller drew an ideologically-motivated portrait of the writer's character gleaned from his literary and other texts to explain his own supposedly moral flaws. Then in the 1970s, following a small thaw in politics, the wind changed again and a mini-revival of sorts took place in literary studies, too, with the publication of some more appreciative assessments of Kosztolányi by László Rónay, Ferenc Kiss, Imre Bori, and István Király, and with the (re)publication of several of his works. The esteemed writer and critic Pál Réz stood behind the grand project of publishing Kosztolányi in full, bringing out not only his well-known novels and short stories, but also his previously unpublished short pieces, with the hope of thus reaching tens of thousands of enthusiastic readers. Indeed, it was a major event in Hungarian literary life when readers could finally read a large selection of Kosztolányi's short stories, as well as his editorials, essays on language, and journalism pieces. The series initiated by Réz was, however, far from complete.

In the 1980s and more so after the regime change of the 1990s a new era began, Arany recalls, and in Hungary it was marked by the belated advent of structuralist and post-structuralist critical approaches to literature. For the first time since Kosztolányi's death it became possible to create systematic scholarly and nonpolitical assessments of his oeuvre within diverse theoretical frameworks. This scholarly imperative was underpinned by the discrete efforts of major writers who saw in Kosztolányi their master and originary influence; among these, authors as diverse as Géza Ottlik, Péter Esterházy, and Ottó Tolnay declared themselves to be heirs to Kosztolányi's legacy. This time the person in charge of the literary and critical attempts to put Kosztolányi back into the center of the canon and thus initiate a veritable Kosztolányi revival was the eminent scholar Mihály Szegedy-Maszák. Szegedy-Maszák brought together a multi-generational team of researchers, postdoctoral and doctoral students who were all committed to bring out a complete critical edition of all the texts, every novel and short story, every poem and translation, every essay and journalism piece, and even every slip of paper ever written by or relating to Kosztolány. This team, currently headed by András Veres and István Dobos, has already published over a dozen highly professional volumes. The theoretical-critical foundations for this critical series were laid by various collective and individual works, among them the 1998 volume 
Bollobás, Enikő. “Arany, Zsuzsanna. Kosztolányi Dezső élete ['The Life of Dezső Kosztolányi’]. Budapest: Osiris, 2017. 692 pp. Illus." Hungarian Cultural Studies. e-Journal of the American Hungarian Educators Association, Volume 11 (2018) DOI: 10.5195/ahea.2018.331

of essays edited by Szegedy-Maszák and Ernő Kulcsár-Szabó, Tanulmányok Kosztolányi Dezsőről ['Essays on Dezső Kosztolányi'] (Budapest: Anonymus) and Szegedy-Maszák’s own 2010 comprehensive monograph, Kosztolányi Dezsö (Budapest: Pesti Kallgram). Following these, it became clear that a scholarly biography of Kosztolányi is desperately needed, as his only existing biography had been written in 1938 by his wife Ilona Harmos (Budapest: Révai), which, besides being dated, was far from inclusive and scholarly. Szegedy-Maszák offered the task to Zsuzsanna Arany, a Kosztolányi expert, author of two books and editor of six volumes on or related to Kosztolányi. Arany began working on the biography in 2011 and completed it in 2017.

Arany's work is a biography proper, giving a minutely detailed account of Kosztolányi's life in its historical, social, and cultural contexts. When putting together the narrative of the writer's life, Arany builds on the solid foundation of personal documents such as diaries, notes, slips of papers, letters, press statements, and interviews; in addition, she cites his journalistic pieces, of which there are thousands, in their first appearance in contemporary papers and journals. Moreover, the biography is well rooted in the time's historical and intellectual contexts, supported by archives sources, historical records, repositories, registries, and the period's journals. In other words, Arany's biography follows the international norms of this scholarly genre, which until recently have not been part of the Hungarian practice.

The book is divided into six sections representing six periods in Kosztolányi's life. The first major section covers the writer's early life, his family, ancestors, and even events preceding his birth; the second covers the years 1885-1902 and discusses Kosztolány's childhood and adolescence in Szabadka; the third gives an account of Kosztolány's first decade in Budapest in 1903-1913, when he attended university, his apprenticeship as a journalist, and the publication of his first volumes of poetry; the fourth section depicts Kosztolány's life from the outbreak of World War I to the Hungarian Soviet Republic, in 1914-1921, and the following retribution, dealing with how both the revolutionary Red Terror and the counter-revolutionary White Terror affected his life; the fifth discusses Kosztolányi's coming of age in the years 1922-1929 and becoming a major poet and novelist; lastly, the sixth section portrays Kosztolányi of the 1930s at the height of national and international fame and then the breakdown of his health leading to his death.

As described, the six sections follow Kosztolány's life events as they are woven into the time's history and culture. For example, the third section dealing with the period between 1903 and 1913 covers Kosztolányi's university years, his bohemian life style, his apprenticeship as a journalist, the beginning of his poetic career, and his love life at the time. Each of these issues is contextualized by focused sketches of the time's social and cultural background: Kosztolány's writing is enriched by his participation in László Négyessy’s famous creative-writing seminar at the University of Budapest and his growing acquaintance with various writer communities of the big city's so-called literary cafés, and all this is framed by the cultural-political map of the period and its portrayal in national papers and journals, as well as by the ambience of Budapest brothels. Moreover, Arany unveils some of Kosztolányi's hitherto little researched interests like, for example, his freemason activities and his neo-Gnosticism as manifest in his involvement in Budapest's spiritist societies. We get an insider's view of his day-to-day struggles with editors of journals and newspapers, his efforts to bring out his poetry volumes, and his battle with censorship during the Soviet Republic. Eventually all these turned this somewhat shy young man 
Bollobás, Enikő. “Arany, Zsuzsanna. Kosztolányi Dezső élete ['The Life of Dezső Kosztolányi’]. Budapest: Osiris, 2017. 692 pp. Illus." Hungarian Cultural Studies. e-Journal of the American Hungarian Educators Association, Volume 11 (2018) DOI: 10.5195/ahea.2018.331

from the province into an increasingly conscious cosmopolitan author who is familiar with the market conditions of literature, the corridors of power, the culture wars, and the interpersonal tensions around him.

The Kosztolányi who emerges from the pages of Arany's biography is a complex intellectual, or one that "contain[es] multitudes," to use a Whitmanesque formulation. In part, Kosztolány's multitudes derive from his erudition: his high-level active knowledge of many languages (German, French, English, Spanish, Portuguese, Italian, and Latin) and ensuing intimate knowledge of many cultures. He was the product of the Zeitgeist as much as he himself helped creating it, thus shaping the cultural climate not only of his age but also of later times. As Arany demonstrates, these multitudes are sometimes contradictory, containing traits of socialist as well as anti-communist thinking, of anti-Semitism as well as philosemitism, and of irredentism as well as internationalism. As we read the book, we understand that, rather than simultaneously held contradictory views, these tendencies together make up the intellectual trajectory that Kosztolányi completed during his fifty-one years. For example, we trace the development of Kosztolányi's utter disillusionment regarding both "red" and "white" political ideas, as well as his dismissal of "Christian revival" ideologies tainted by anti-Semitism, and eventually his withdrawal from all political and professional battles. By the end of Arany's book we get the portrait of a fully mature intellectual, who by the 1930s proclaimed a joint HungarianEuropean identity, became apolitical, refused to share any ideas with any political formation, and believed only in the power of the intellect. This is the Kosztolányi who became the paragon of intellectual growth for later generations, the self-reflective thinker who had the courage to revise formerly held positions, and the mind that was capable of changing and expanding. This is the author who rightly served as the master for Ottlik, Esterházy, and Tolnay; this is the Kosztolányi whose figure - open-minded, sophisticated yet vulnerable and fallible, and in every way human-we come to understand, and perhaps even love after reading this grand biography of his written by Zsuzsanna Arany. 